University of Louisville

ThinkIR: The University of Louisville's Institutional Repository

Electronic Theses and Dissertations

1939

\title{
The influence of temperature on the internal secretory activity of transplanted ovaries in the rat.
}

Arthur K. Lampton 1915-1978

University of Louisville

Follow this and additional works at: https://ir.library.louisville.edu/etd

Part of the Pathological Conditions, Signs and Symptoms Commons

\section{Recommended Citation}

Lampton, Arthur K. 1915-1978, "The influence of temperature on the internal secretory activity of transplanted ovaries in the rat." (1939). Electronic Theses and Dissertations. Paper 1828.

https://doi.org/10.18297/etd/1828

This Master's Thesis is brought to you for free and open access by ThinkIR: The University of Louisville's Institutional Repository. It has been accepted for inclusion in Electronic Theses and Dissertations by an authorized administrator of ThinkIR: The University of Louisville's Institutional Repository. This title appears here courtesy of the author, who has retained all other copyrights. For more information, please contact thinkir@louisville.edu. 


\section{UNIVERSITY OF LOUISVILLE}

the influence of temperature on the internal secretory Activity of transplanted OVaries in the Rat.

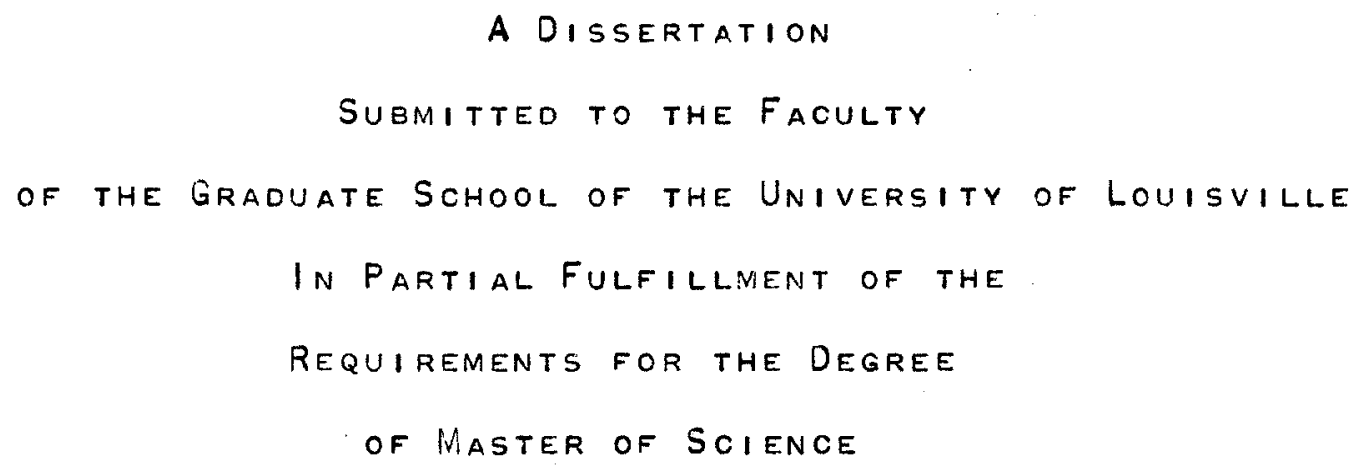




\section{DATE $5-2 ? \cdot 31$}

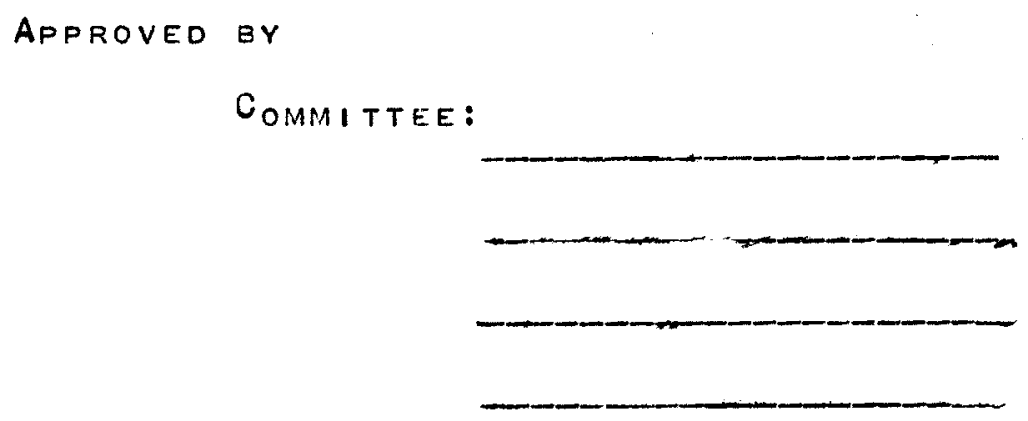

ENGLISH DEPARTMENT 
I WISH TO EXPRESS MY GRATITUDE AND APDRECIATION TO DOCTOR

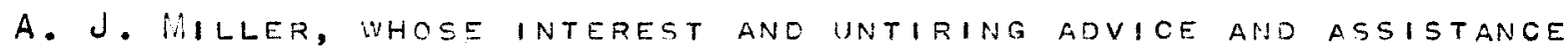
HAVE MADE THIS WORK POSSIBLE. I AM GREATLY INDEBTEO TO HIM NOT ONLY FOR HIS GUIDANGE THROUGH THIS PARTIOULAR PIECE OF WORK, But also for the valuable training MHICH He has given so FRELY.

For their timely aOVice and encouragenent, I also Wish to thank DOCTORs Harolo Gordon, H. C. LaWGon, and L. A. Gray. 
The Influence of temperature on the Internal SECRETORY ACTIVITY OF TRANSPLANTED

OVARIES IN THE RAT 


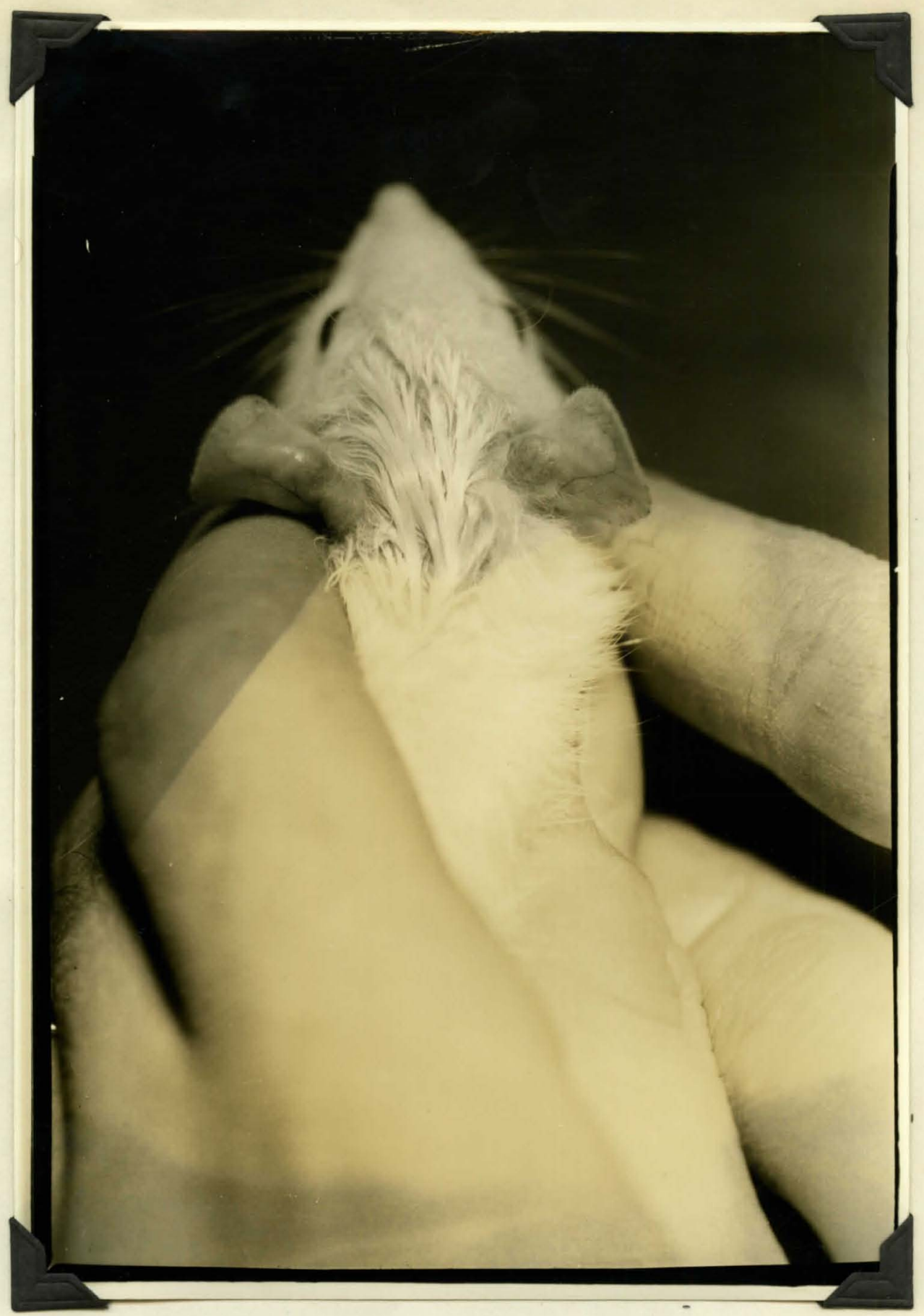

RAT No. ||$-B-\mid$

BOTH EARS CONTAIN LARGE OVARIAN TRANSPLANTS. 
1. INTRODUCTION

2. Materials and Methods

A. ANIMALS 5

B. SURGERY 5

C. TEMPERAtURE 6

D. Colorimetry 6

E. AUTOPSY 8

3. Reuslts 9

A. FIG. I UTERI OF HIGH AND

LOW TEMPERATURE ANIMALS 9

B. CHART No. I 10

C. FIG. II SECTIONS OF EAR

CONTAINING OVARIAN TRANSPLANTS 12

D. Chart No. 11 13

E. Fig. HII Prostate of a castrate and

OF A ORMAL ANI HAL 15

F. Chart No. 11116

G. Fig. iv prostate of lov and high TEMPERATURE MALES 18

H. CHART NO. IV 19

I. FIG. V SECTIONS OF EARS CONTAINING OVARIAN TRANSPLANTS 21

4. DISCUSSION 22

5. CONCLUSION 26

6. SUIMMARY 27

7. RefERENCES 28 
INTROOUCTION 
The influence of temperature on the Internal secretory activity of transplanted ovaries in the rat

INTEREST IN THE INTERNAL SECRETORY ACTIVITY OF THE GONADS HAS BEEN ENHANCED RECENTLY BY THE DEVELOPMENT OF METHOdS OF assay. Pezaro, in lall, first used the Cock's Comb Method of bioassay of male sex hormone. A few years later, loewe and Frank made the use of castrate mice for the identification of the female sex hormone practical. Since that time, colorimetric METHODS FOR THE IDENTIFICATION AND MEASUREMENT OF BOTH THE MALE AND FEMALE SEX HORMONES HAVE BEEN INTRODUCED.

In the LAST TWENTY YEARS, OVARIAN TRANSPLANTATION HAS BECOME A VERY POPULAR METHOD FOR STUDYING THE INTERNAL SECRETORY ACTIVITY OF THAT ORGAN. MOST EXPERIMENTERS AGREE THAT INTRA-AgDOMINAL TRANSPLANTATION OF THE OVARY RESULTS IN INTERNAL SECRETORY ACTIVITY, WHICH, AS MANIFESTED BY CHANGES IN OTHER ORgans (UTERUS, VAGINA, CLITORIS, MAMIMAE) IS NOT GREATLY ALTERED.

$$
\text { GARDNER' FOUND THAT OVARIES, WHEN TRANSPLANTED INTO THE }
$$
testes of MICE CONTINUE to secrete OESTROgENIC HORMONES, bUt PRODUCE NO MARKED EFFECT ON THE SEHINAL VESICLES AND PROSTATE. SEVEPAL NORKERS, ON THE OTHER HAND, FOUND THAT INJECTIONS OF LARGE DOSES OF OESTROGENIC HORMONE PRODUCED MUSCULAR AND CONNECTIVE TISSUE HYPERTROPHY AS MELL AS INVOLUTION OF, THE EPITHELIUM of the ACCESSORY TRACT.

$$
\text { INJECTIONS OF ANOROGENIC SIJBSTANCES INTO CASTRATE MALE }
$$
rats and mice cause the epithelium of the accessory glands to RETURN TO NORMAL. RECENTLY, THIS PROCEDURE HAS BEEN ADOPTED as a MEANS OF IDENTIFYing andRogenic SUBStances. THIS EFFEct canNOT BE SIMULATED BY THE INJECTION OF ANY QUANTITY OF OESTROGENIC HORMONE. 
HILL ${ }^{2}$ BY TRANSPLANTING OVARIES INTO THE EARS OF CASTRATE male mice, and subsequently keEPING these mice in the proper ENVIRONMENTAL TEMPERATURE, COULD BRING ABOUT A RESTORATIDN OF

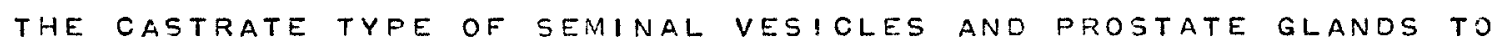
NORMAL. THIS EFFECT WAS OBSERVED IN HIS GROUP OF MICE MHICH WERE KEOT IN A COOL ENVIRONMENT (22 DEGREES C.), BUT NOT IN THE groUP OF ANIMALS IN A WARM ENVIRONMENT (33 DEgREES C.). ThI5, he tentatively EXPLAINED, IS DUE TO THE fact that the TEMPERATURE OF THE EAR OF ANIMALS IN A COOL ENVIRONMENT IS NEARLY THAT OF THE SCROTUM, WHEREAS THE EAR TEMPERATURE OF THE ANIMALS IN A WARM ENVIRONMENT IS MORE NEARLY THAT OF THE ABDOMEN. THIS, he CONCLUDED, SUgGests that TEMPERATURE PARTLY CONTROLS THE INTERNAL SECRETORY ACTIVITY OF THE OVARY.

In a later paper, the same author 3 presented data WHICH SUGGESTED THAT THE ANDROGEN PRODUCEO BY THE OVARY IS PERHAPS CHEMICALLY DIFFERENT FROM THAT SECRETED EY THE TESTES, BUT THAT THE TWO aRE Closely RELated If NOT PHYSIOLOGICALLY IDENTICAL. DEANSELY 4 REPEATED THE WORK OF HILL USING RATS INSTEAD OF MICE. FROM HER WORK, SHE CONCLUDEN THAT THE "ANDROGENIC ACTIVITY DOES NOT DEPEND ON THE TEMPERATURE AT WHICH THE RAT IS KEPT; IT IS ASSOCIATED WITH THE LUTEINIZATION OF THE THECA INTERNA OF THE FOLLICLES WHICH OCCURS COMMONLY IN ESTAELISHEO GRAFTS. THIS THECA LUTEINIZATION SEEMS TO OCCUR INDEPENDENTLY OF THE TEMPERATURE AT WHICH THE ANIMAL IS KEPT. THE Fact THAT HILL WAS ABLE TO CONTROL THE ANDROGENIC SECRETION OF OVARIAN GRAFTS IN MICE BY TEMPERATURE REgULATION SUGGESTS THAT HE THEREBY INFLUENCEO THE HISTOLOGICAL DEVELOPMENT OF THE GRAFT."

THE INTRODUCTION OF SYNTHETIC MALE SEX HORMONES INTO THIS 
FIELD OF STUDY HAS FURTHER ADDED TO THE COMPLEXITY OF THE SITUATION. NELSON AND MERCKEL FoUND THAT DAILY INJECTICNS OF ANDOSTERONE INTO SPAYED FENALE RATS PREVENTED THE USUAL CASTRATION CHANGES.

GREENE, BURRIL, AND IVY FOUND THAT THE ADNINISTRATION OF A SUFFICIENT QUANTITY OF TESTOSTERONE PROPIONATE TO NEW BORN FEMALE RATS WOULD CAUSE A MASCULINIZATION OF THE EXTERNAL GEN I TALIA.

PreViously, Greene and IVY ${ }^{7}$ had SHOWN that intersexuality, AS MANIFESTED BY A RUDIMENTARY VAGINA AND ENLARGED CLITORIS, COULD BE PRODUCED BY INJECTICNS OF TESTOSTERONE INTO PREGNANT FEMALES DURING THE LATTER PART OF PREGNANCY.

SALMON $^{8}$ OBSERVED THE EFFECT OF TESTOSTERONE PROPIONATE ON THE GENitAL TRACT OF IMATURE FEMALE RATS AND FOUNO: (1) THAT SINGLE INJECTIONS CAUSE A PREMATURE OPENING OF THE VAGINA, (2) THAT CONTINUOUS INJECTIONG CAUSE AT FIRST A PROLONGATION OF THE CORNIFIED CELl stage of the cycle (5-8. days) With a subsequent SUPPRESSION OF THE OESTRUS CYCLE AS LONG AS THE INJECTIONS WERF CONTINUED, (3) THAT THE UTERI OF ANIMALS RECEIVING INJECTIONS SHOW ENLARGEMENT WITH HYPERTROPHY OF MUSCLE AND PROLIFERATION OF MUCOSA fS EARLY AS SEVENTY-TVO HOURS AFTER THE FIRST INJECTION.

Later, Mazer and Mazef 9 bought out the fact that proLONGED ADMINISTRATION OF TESTOSTERONE PROPIONATE TO EOTH I MiMATURE aNd Mature fEMALE RATS PRODUCES ATROPHY OF THE OVARIES AND UTERI. THEY ALSO POINT OUT THAT THE OVARIAN ATROPHY PRODUCED BY PROLONGED TREATMENT WITH TESTOSTERONE IS IN CONTRAST TO THE OVARIAN STIMULATION FOLLOWING RELATIVELY GHORT TREATMENT, 


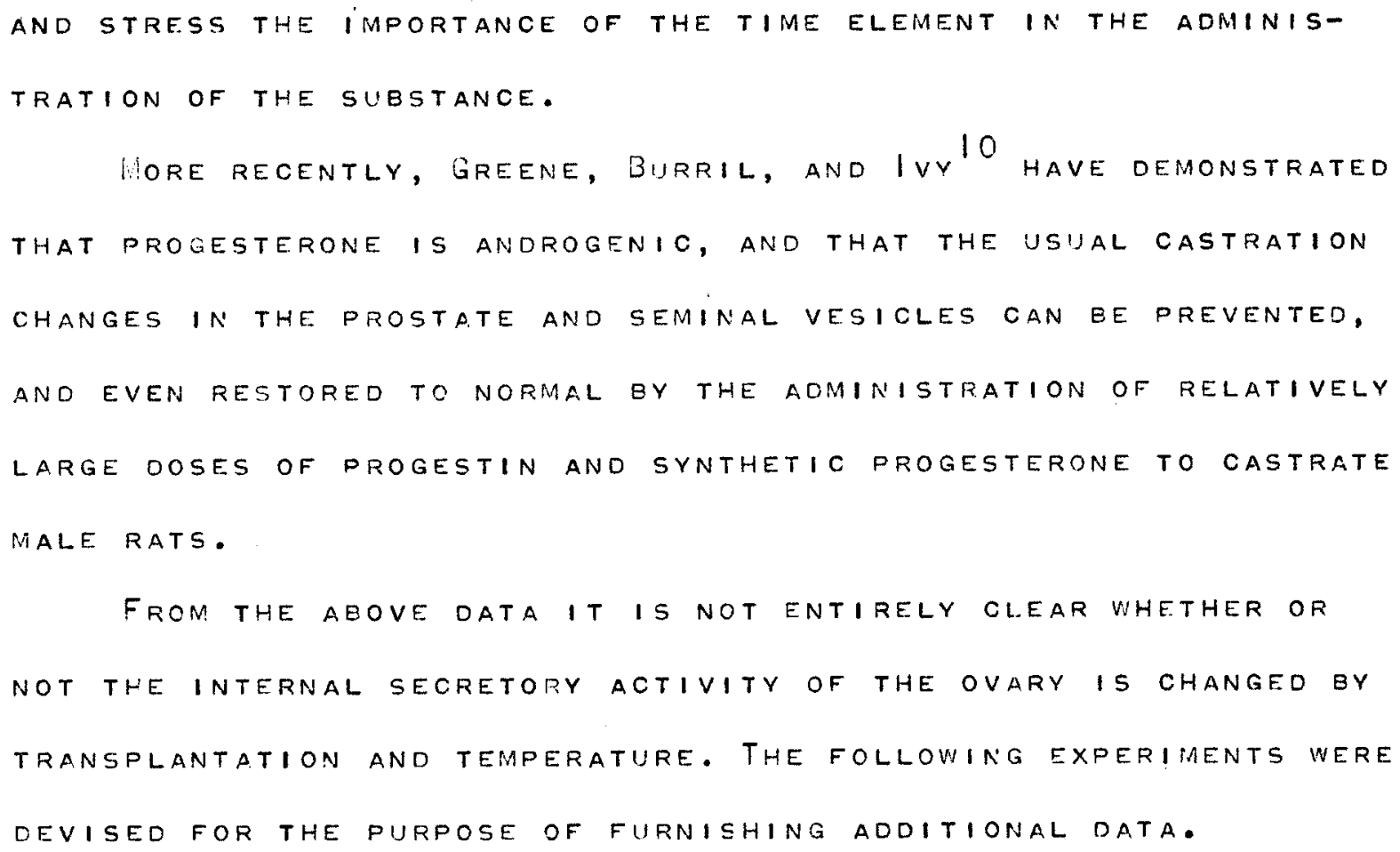


MATERIALS

AND

METHODS 


\section{MATERIALS AND METHODS}

ANIMALS.

WHITE RATS OF ORDINARY LABORATORY STOCK AND OF YOUNG AND SUBADULT AGE WERE DIVIDED INTO FIVE GROUPS AS FOLLOWS:

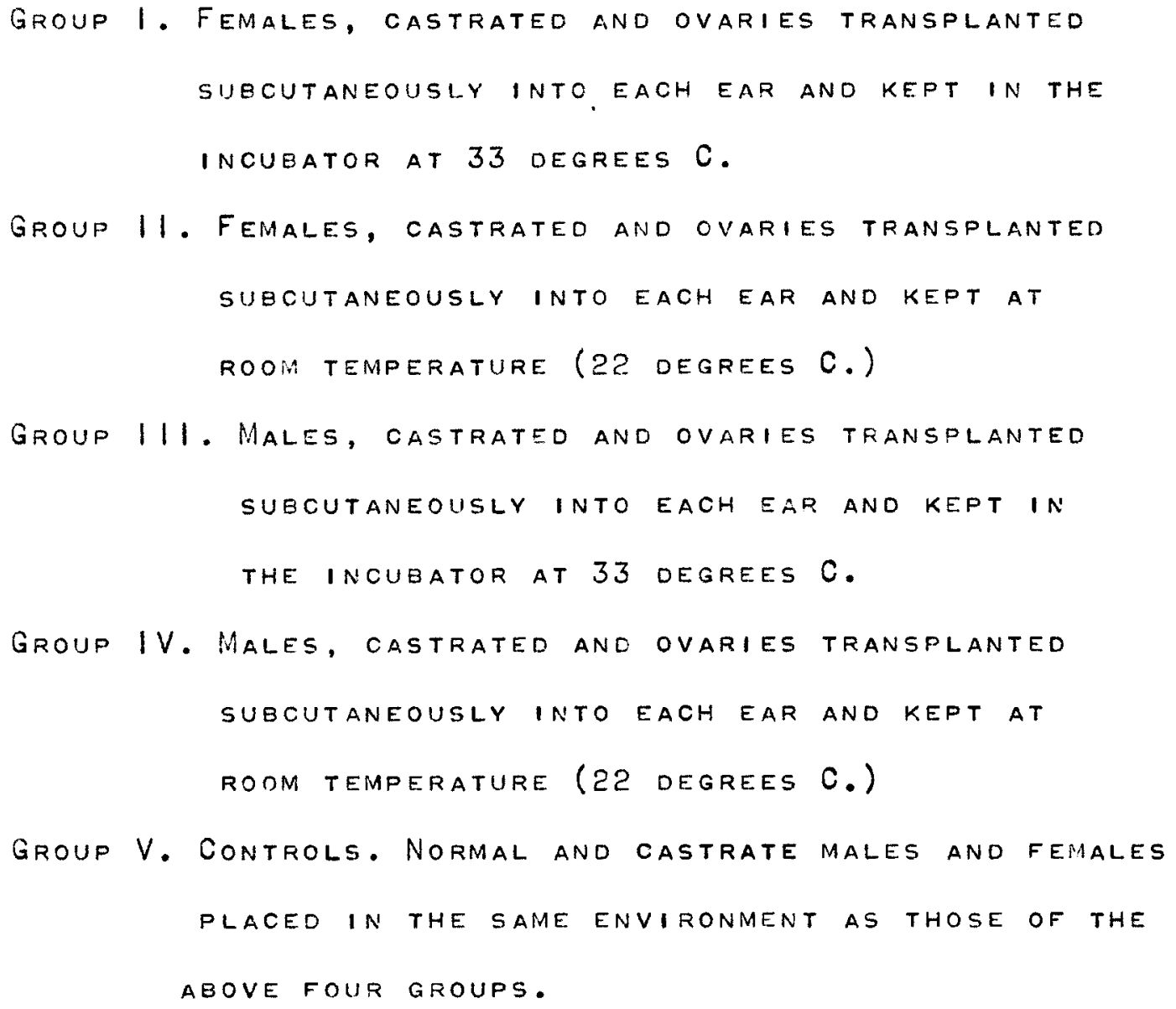

SURGERY.

THE OVARIES WERE REMOVED UNoER ETHER ANESTHESIA through A LOW MIDLINE ABDOMINAL INCISION AND PLACED IMMEDIATELY IN NORMAL SALINE.THE TRANSPLANTATION SITE (EAR) WAS SHAVED AND WASHED WITH 7O\% ALCOHOL, FOLLOWED BY NORMAL SALINE. A SMALL INCISION I-2 MM. IN LENGTH WAS THEN MADE THROUGH THE SKIN ON THE DORSAL SIDE OF THE EAR NEAR THE BASE. WITH THE AID OF CURVED FORCEPS, THE SKIN WAS SEPARATED FROM THE SUBCUTANEOUS TISSUES TO FORM A RECEPTIVE POUCH INTO MHICH THE OVARY WAS PLACED AND THE INCISION CLOSED WITH a SINGLE SUTURE. 
The males inere castrated in the usual way.

IENPERATURE.

High environmental temperatures (33 degrees C.) were

EFFECTED BY PLACING THE ANIMALS IN A THERMOSTATICALLY CONTROLLED INCUBATOR WHICH MAINTAINED A CONSTANT TEMPERATURE OF 33 DEGREES C.

LOW ENVIRONMENTAL TEMPERATURES WERE EFFECTED BY PLACING the ANIMALS IN a WELL VENTILATED ROOM, IN WHICH THE TEMPERATURE WAS APPROXIMATELY 22 DEgREES 0 .

IYPES AND NETHODS OF OBSERVATION.

DETERMINATION OF URINARY ANDROGGENS.

TWENTY-FOUR HOUR URINE SAMPLES. WERE COLLECTED AND ANALYZED FOR ANDROGENIC SUBSTANCES BEFORE THE ANIMALS WERE

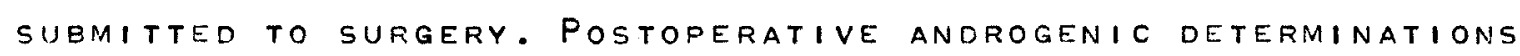
WERE cONE AT VARIOUS INTERVALS.

THE URINE WAS OBTAINED EY PLACING EACH ANIMAL IN AN EIGHT INCH GLASS FUNNEL, TO WHICH WAS ATtached a Clean, Well stoppered collecting bottle. Wire gauze was placed in the apex of the FUNNEL TO PREVENT FECAL CONTAMINATION.

For DETERMINING the URINARY aNdROgENS, the COLORI-

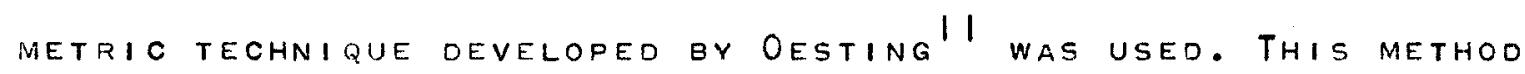

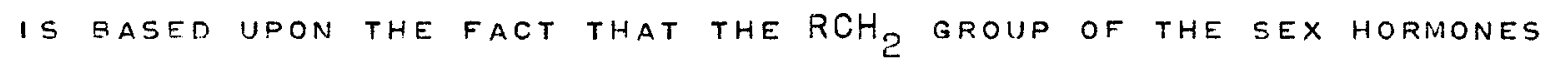
When ReActed With VARIOUS substances (E.g. Meta dinitro benzene) PRODUCES A CHROMAGEN WHICH CAN BE MEASURED COLORIMETRICALLY. IN the case of the male hormones, a Violet color IS FORMED.

THIS TECHNIQUE BRIEFLY IS AS FOLLOWS. THE 24 HOUR

URINE SAMPLE IS ACIDIFIED WITH CONGENTRATED H $2 \mathrm{SO}_{4}$ TO A PH Below ONE, AND aUtoclaved at 15 LBS. PRESSURE For I5 MINUTES. 
The uRine is then extracted With benzene and ether. The ether EXTRACT IS SAPONIFIED WITH 10\% SODIUM HYDROXIDE TO REMOVE THE FEMALE HORMONES. THE ETHER IS EVAPORATED and the hORMONE RESIDUE DISSOLVED IN 60\% ALCOHOL. THIS ALCOHOLIC EXTRACT IS REACTED WITH META DINITRO BENZENE AND MEASURED IN A SPECIAL tYPE OF COLORIMETER DESIGNED BY DR. OESTING.

UP TO THE PRESENT TIME, EUt VERY LitTLE DATA HAS APPEARED in the LITERATURE CONCERNING THE STANDARDIZATION OF THE COLORIMETRIC TECHNIQUE. THE QUESTION AROSE AS TO MHETHER THESE URINE EXTRACTS CONTAINED ACTIVF HORMONE, OR WHETHER THE COLOR PROduced was due to suestances other than the male hormones. It

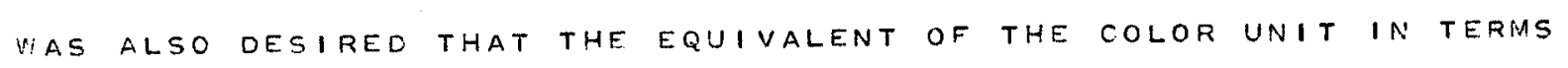
of actual Milligrais of pUre male hormone be kNOWN. To answer THESE QUESTIONS, THE FOLLOWING EXPERIMENTS WERE DONE.

White LEghorn Cafons WERE INJECTED WITH CONCENTRATED URINE EXTRACTS AND OBSERVED FOR GHANGES IN COMB SIZE ANO COLOR. IN ONE CASE, FORTY COLOR UNITS WERE GIVEN OVER A PERIOD OF FIVE DAYS. BY THE SIXTH DAY, THE COMB SHONED AN INCREASE IN SIZE OF 22 MM., MEASURED IN LENGTH DLUS heIght.

THE STANDARD UNIT OF MALE SEX HORMONE IS THE CAPON UNIT, AND IS DEFINED AS THE AMOUNT OF MATERIAL WHICH WHEN DIVIDED INTO FIVE EQUAL DOSES AND INJECTED DAILY INTO WHITE LEgHORN CAPONS, WILL PRODUCE by the SIXTH DAY AN INCREASE IN COMB SIZE. OF 3-4 MM., MEASURED IN LENGTH PLUS HEIGHT.

THUS BY DEFINITION, FORTY COLOR UNITS ARE EQUIVALENT TO APPROXIMATELY 5-7 CAPON UNITS, OR ONE CAPON UNIT IS EQUIVALENT TO ABOUT SIX COLOR UNITS. THIS IS CONSISTENT WITH OTHER WORK WHICH HAS BEEN DONE. 
IN ORDER TO DETERMINE THE HORMONE EQUIVALENT OF THE COLOR unit, PURE crYstalline testosterone, ANDROSTERONE, and transDEHYDro androsterone* NERE disSOLVED IN $60 \%$ alcohol and MEASURED COLORIMETRICALLY. THE FolLOVING FIGURES WERE obTAINED:

ONE color UNit IS EqUivalent to 0.265 Mgm. of testosterone. ONE COLOR UNIT IS EQUIVALENT TO 0.093 MGM. OF ANOROSTERONE. ONE COLOR UNIT IS EQUIVALENT TO 0.058 MgM. OF TRANS-DEHYDROANDROSTERONE.

To RULE oUt the pOSSIBILITY of the PRESENCE of fEMALE horiones in the extracts, castrate fERiale rats were injected WITH THESE URINE EXTRACTS AND VAGINAL SMEAR STUOIES CARRIED out. All of these tests were negative.

These data indicate that there is a rather close correlaTION BETUEEN THE COLORIMETRIC AND OTHER METHODS OF ASSAY FOR THE MALE SEX HORMONES.

VAGINAL SMEAR STUDIES.

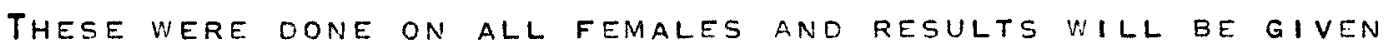
in the PROPER place.

OIHEER ANTE MOORTEM OESERVATIONS.

$$
\text { Other ante mortem observations SUCH as body Weight, }
$$

ENLARGEMENT OF THE CLITORIS, ETC., WERE MADE AND DATA CONCERNing tHESE WILL EE GIVEN LATER.

POSTMORTEM EXAMINATION.

After the oesired time had elapsed, the animals were SACRIfICED. THE EARs of all animals were sectioned and the TRANSPLANTS STUDIED AAICROSCOPISALLY. THE UTERI, SEMINAL VESICLES AND PROSTATES WERE EXAMINED BOTH GROSSLY AND MICROSCOPICALLY.

* Supplied by the ciba pharmaceutical co. 
RESULTS 


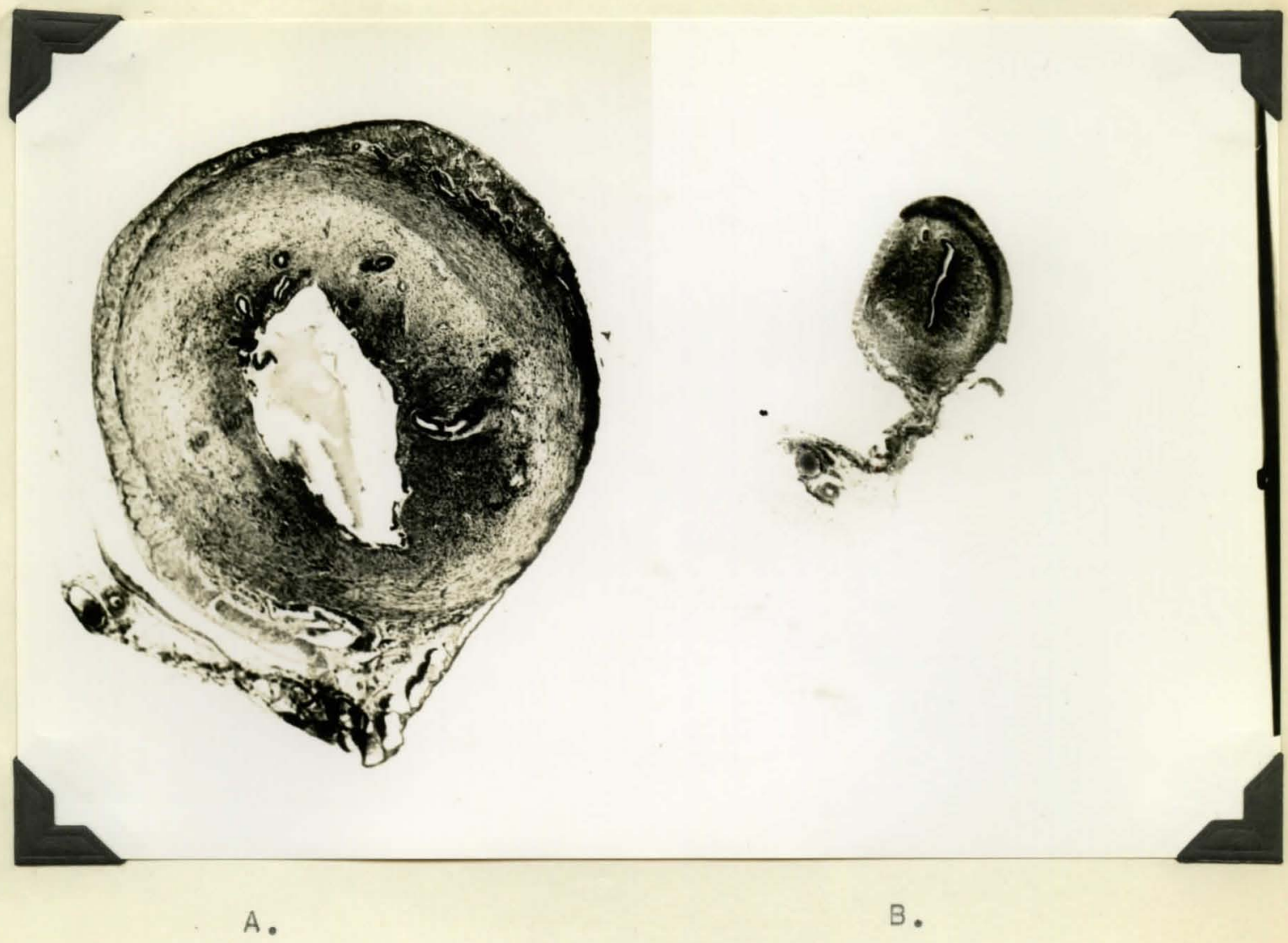

$F \mid G . I$

A. PHOTOMICROGRAPH. CROSS SECTION OF UTERINE HORN OF AN IMAL | |-A-||, CASTRATED AND OVARIES TRANSPLANTED INTO THE EARS, AND KEPT IN A HIGH ENVIRONMENTAL TEMPERATURE ( 33 DEGRESS C. ).

B. Same of a Similarly treated Female, | |-B-4, Kept in A LOW ENVIRONMENTAL TEMPERATURE (22 DEgRESS C.). 
SERIES II-A

FEMALES

33 DEGREES C.

\begin{tabular}{|c|c|c|c|c|c|c|c|}
\hline \multirow{2}{*}{$\begin{array}{l}\text { RAT. } \\
\text { No. }\end{array}$} & \multirow{2}{*}{$\begin{array}{c}\text { TYPE } \\
\text { OF } \\
\text { AN IMAL }\end{array}$} & \multirow{2}{*}{$\begin{array}{l}\text { DAYS } \\
\text { OF } \\
\text { OBSER- } \\
\text { VATION }\end{array}$} & \multirow{2}{*}{$\begin{array}{c}\text { UTERUS } \\
\text { (MICROSCOPY) }\end{array}$} & \multicolumn{2}{|c|}{ TRANSPLANTS } & \multicolumn{2}{|c|}{$\begin{array}{l}\text { URINARV } \\
\text { ANDROGENS }\end{array}$} \\
\hline & & & & FOLLICULAR & LUTEINIZED & $\begin{array}{l}\text { AVE. PRE } \\
\text { OPERATIVE }\end{array}$ & $\begin{array}{l}\text { AVE.POST } \\
\text { OPERATIVE }\end{array}$ \\
\hline $\mid 1-A-2$ & $C \& T$ & 65 & NOT ATROPHIC & ++ & ++++ & $0.4 \mathrm{C} . \mathrm{U}$. & $0.0 \mathrm{C.U}$. \\
\hline $11-A-3$ & $C \& T$ & 113 & NOT ATROPHIC & ++ & +++4 & $2.0 \mathrm{c.U}$. & $0.6 \mathrm{C.U}$. \\
\hline||$-A-4$ & $C \& T$ & 103 & NOT ATROPHIC & ++++ & + & $0.0 \mathrm{c.u}$. & $1.04 \mathrm{C} .1$. \\
\hline||$-A-||$ & $C \& T$ & 116 & NOT ATROPHIC & ++ & +++4 & 0.6 C.U. & $0.87 \mathrm{C.U}$. \\
\hline $1:-A-12$ & C\&T & 122 & NOT ATROPHIC & ++ & ++ & $0.9 \mathrm{c} . \mathrm{U}^{\circ}$ & $2.16 \mathrm{C.U}$. \\
\hline $11-A-15$ & $C \& T$ & 78 & NOT ATROPHIC & + & $+4+$ & $0.0 \mathrm{c.U}$. & $1.6 \mathrm{c.J}$. \\
\hline
\end{tabular}

Ave. $\quad 0.63$ C.U. 1.22C.U.

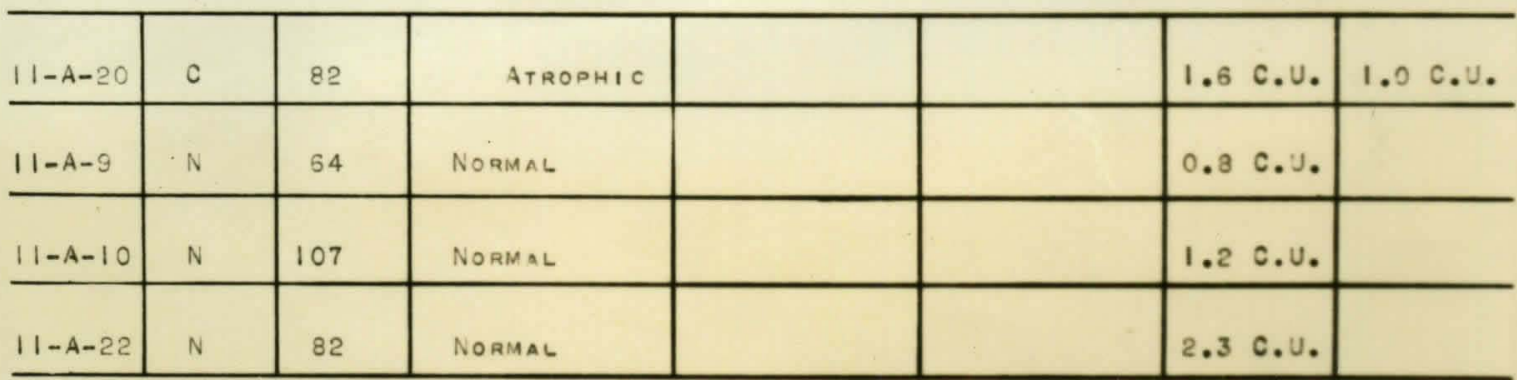

CODE: C INDICATES CASTRATION

T INDICATES TRANSPLANTATION

N NORMAL

- Indicates type and degree of oEvelopment

C.U. COLOR UNIT 
GROUP I. FEMALES

THIS GROUP CONSISTED OF TEN ANIMALS, OF WHICH SIX WERE

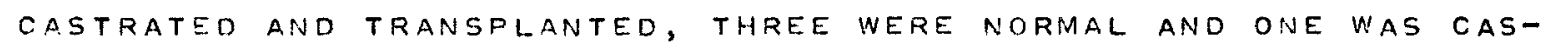
trateo. The latter four animals served as controls. These animals were placed in a thermostatically controlled incueator at 33 DEgREES C. SeE OHART No.1.

ANDROGENIC EINOINGS:

The postoperative aVerage anorogenic outPut of THIS GROUP WAS SLIGHTLY INCREASED OVER THE PREOPERATIVE AVERAgE. (CHART NO.I)

VAGINAL SMEAR STUUDIES:

THESE FAILED TO SHOW ANYTHING IN THE WAY OF A NORMal oEstrus cycle. There was, hOWEVER, EVIdence of SLIGHT oEstrogenic stimulation, as manifested by a sudden decrease iv LEUCOCYTES AND A SHARP RISE IN CORNIFIED AND NUCLEATED EPITHELIAL CELLS. THIS EFFEct WAS TRANSIENT, HOWEVER, LASTING ONLY A FEW HOURS.

\section{POSTMORTEM EXAMINATION :}

at the time the animals were killed, the uteri of ALL SIX OF THE EXPERIMENTAL ANIMALS WERE FOUND TO BE LARGE, WELL VASCULARIZEO AND NORMAL IN APPEARANCE.

MICROSCOPIC EXAMINATION OF THE UTERI REVEALED NO EVIDENCE OF ATROPHY. (FIG.I-A). In all cases there was EVIdence of ovarian influence. The uteri of three of the six experiMENTAL ANIMALS SHOWED EVIDENCE OF BOTH FOLLICULAR AND CORPUS LUTEUM HORMONES, WHEREAS THE REMAINING THREE SHOMED EVIDENCE OF FOLLICULAR HORMONE STIMULATION ONLY. 


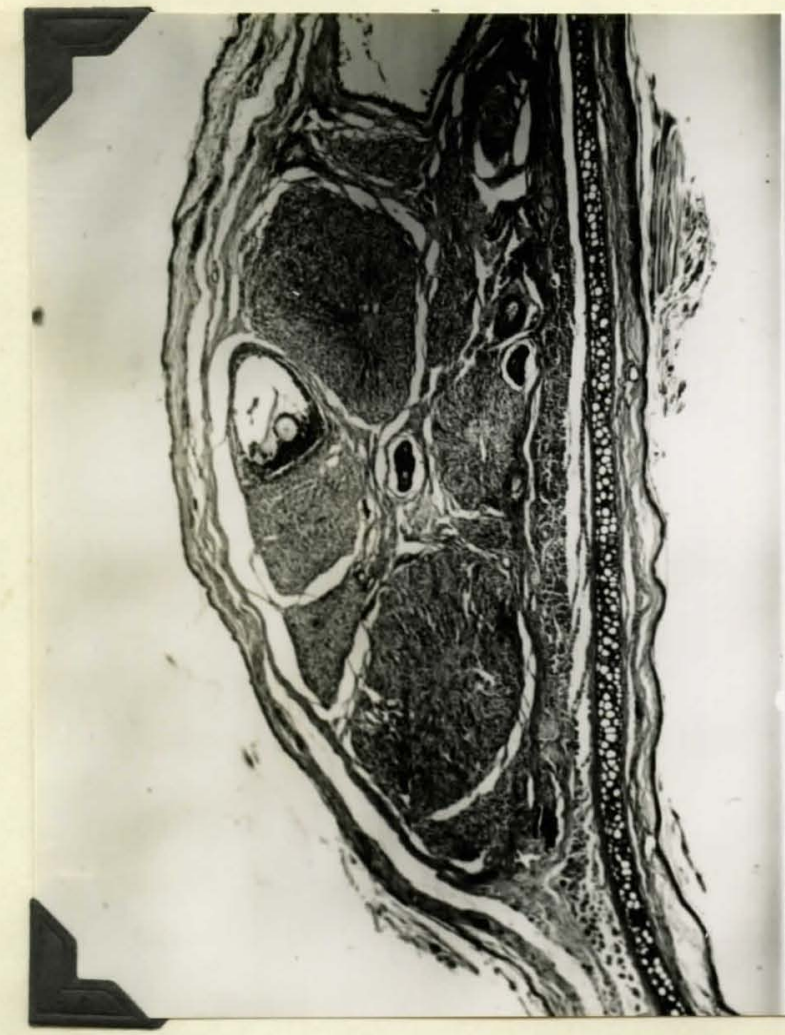

A.

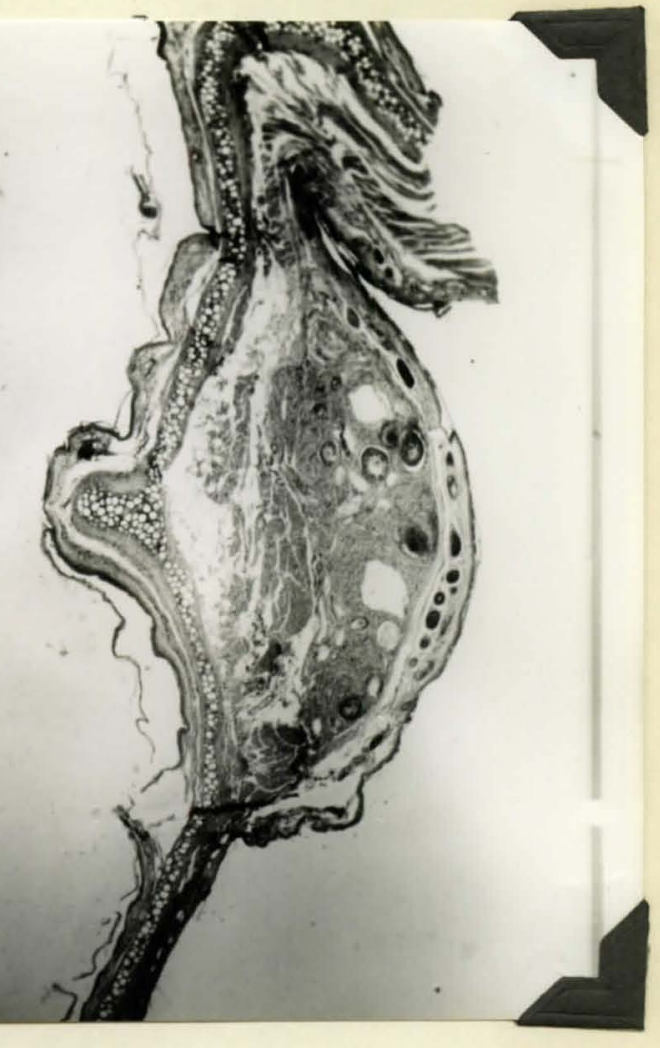

B.

$F$ IG. I I

A. PHOTOMICROGRAPH. CROSS SECTION THROUGH PORTION OF 4 है EAR CONTAINING OVARIAN TRANSPLANT OF ANIMAL $1|-A-| \mid$, A CASTRATED FEMALE, KEPT IN A HIGH ENVIRONMENTAL K. TEMPERATURE ( 33 DEGREES C.).

B. Same of a SIMILARLy treated aNIMAL, I |-B-4, KEPT IN a LoW enVironmental temperature (22 degrees C.). 
CHART No. II

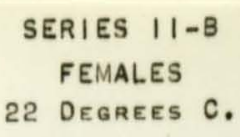

\begin{tabular}{|c|c|c|c|c|c|c|c|}
\hline \multirow{2}{*}{$\begin{array}{l}\text { RAT } \\
\text { No. }\end{array}$} & \multirow{2}{*}{$\begin{array}{c}\text { TYPE } \\
\text { OF } \\
A_{N} \text { IMAL }\end{array}$} & \multirow{2}{*}{$\begin{array}{c}\text { DAYS } \\
\text { OF } \\
\text { OBSER- } \\
\text { VATION }\end{array}$} & \multirow[b]{2}{*}{ (MICROSCOPY) } & \multicolumn{2}{|c|}{ TRANSPLANTS } & \multicolumn{2}{|c|}{$\begin{array}{c}\text { URINARY } \\
\text { ANDROGENS }\end{array}$} \\
\hline & & & & FOLLICULAR & LUTEINIZED & $\begin{array}{l}\text { AVE. PRE- } \\
\text { OPERATIVE }\end{array}$ & $\begin{array}{l}\text { AVE.POST } \\
\text { OPERATIVE }\end{array}$ \\
\hline$|1-5-1|$ & $C \& T$ & 70 & ATROPHIC & ++ & ++ & $1.6 \mathrm{c} . \mathrm{U}$ & $0.0 \mathrm{C.U}$. \\
\hline $11-9-2$ & $C \& T$ & 70 & ATROPHIC & +4 & & $3.2 \mathrm{C.U}$ & $0.9 \mathrm{C.U}$. \\
\hline $11-8-3$ & $C \& T$ & 70 & ATROPHIC & ++ & ++ & $1.2 \mathrm{C} . \mathrm{U}$ & $0.9 \mathrm{C} . \mathrm{U}_{\text {. }}$ \\
\hline $\mid 1-9-4$ & $C \& T$ & 70 & ATROPHIC & ++ & ++ & I. .2 c.u & $0.8 \mathrm{C.U}$. \\
\hline||$-3-5$ & C\&T & 70 & ATROPHIC & + & & $0.0 \mathrm{c} . \mathrm{U}$ & $0.5 \mathrm{C.U}$. \\
\hline $\mid 1-8-6$ & $C \& T$ & 66 & ATROPHIC & + & & $0.8 \mathrm{C.U}$ & $0.9 \mathrm{C.U}$. \\
\hline $\mid 1-3-7$ & C\&T & 69 & NOT ATROPHIC & +4 & + & $1.2 \mathrm{C.U}$. & I.2 C.U. \\
\hline $11-8-8$ & CQT & 69 & ATROPHIC & ++ & ++ & $0.8 \mathrm{C.U.}$ & $0.8 \mathrm{C} . \mathrm{U}$. \\
\hline $11-3-9$ & $C \& T$ & 69 & ATROPHIC & +4 & +4 & $1.2 \mathrm{C.U}$. & $1.3 \mathrm{c.J}$. \\
\hline
\end{tabular}

Ave. $\quad 1.2$ C.U. $0.83 \mathrm{C.U}$.

\begin{tabular}{|c|c|c|c|c|c|}
\hline $11-8-12$ & c & 69 & ATROPHIC & $0.8 \mathrm{c.J}$. & $0.2 \mathrm{c.u}$. \\
\hline $\mid 1-8-13$ & c & 59 & ATROPHIC & I.2 c.u. & $0.3 \mathrm{c.u}$. \\
\hline $\mid i-3-14$ & N & 69 & NOT ATROPHIC & $0.2 \mathrm{c} .0$ & \\
\hline $11-8-15$ & N & 69 & NOT ATROPHIC & $0.56 \mathrm{c.u}$ & \\
\hline
\end{tabular}

Code: C indicates Castration

T INDICATES TAANSPLANTATION

N NORMAL

- indicates trpe and degaee of development

C.U. COLOR UNIT 
MICROSCOPICALLY, THE OVARIAN TRANSPLANTS OF THIS GROUP WERE WELL DEVELOPED, WELL VASCULARIZED AND SHOWED A PREPONDERANCE OF cORPUS lJTEUM TISSUE. (FIG, il-A). Group II. FEMALES.

THIS GRDUP CONSISTED OF THIRTEEN ANIMALS, OF WHICH NINE WERE CASTRATED AND TRANSPLANTED, TWO WERE CASTRATE ONLY, AND TWO WERE NORMAL ANIMALS. THE LATTFR FOUR ANIMALS SERVED AS CONTROLS. (CHART NO. II). THIS GROUP WAS KEPT IN A LOW ENVIRONMENTAL t MPERATURE (22 DEgRESS C. ).

ANDROGENIC FINDINGS:

AS SHOWN EV CHART NO. II, THE AVERAGE POSTOPERATIVE LEVEL OF THIS GROUP AS A WHOLE WAS SLIGHTLY LOWER THAN THE AVERAGE PREOPERATIVE LEVEL.

\section{VAGINAL SMEAR SIUㅁI트로}

VAGINAL SMEAR STUDIES ON THIS GROUP OF ANIMALS FAILED TO REVEAL ANV EVIDENCE OF OESTRUS EXCEPT IN ONE CASE, ANIMAL II-B-7, WHICH SHOWED EVIDENCE OF SLIGHT OESTROGENIC STIMULATION

\section{POSTMORTEM EXAMINATION:}

AT THE TIME OF AUTOPSY, THE CLITORA OF ALL ANIMALS OF THIS GROUP WERE ENLARGED. THE UTERI OF EIGHT OF THE EXPERIMENTAL ANIMALS WERE AVASCULAR, THREAD-LIKE AND ATPOPHIC. THIS ATROPHY WAS EVEN IORE MARKED MICROSCOPICALLY. (FIG. $1-B)$. THE EXCEPTION IN THIS GROUP WAS ANIMAL |I-B-7, WHICH SHOWEO A NORMAL UTERUS. THE EXPLANATION FOR THIS IS NOT EVIDENT. IT IS BELIEVED, HOWEVER, THAT THE OVARIES WERE NOT COMPLETELY REMOVED AND THAT SOME OVARIAN TISSUE MAS LEFT IN THE ABDOMINAL CAVITY. 


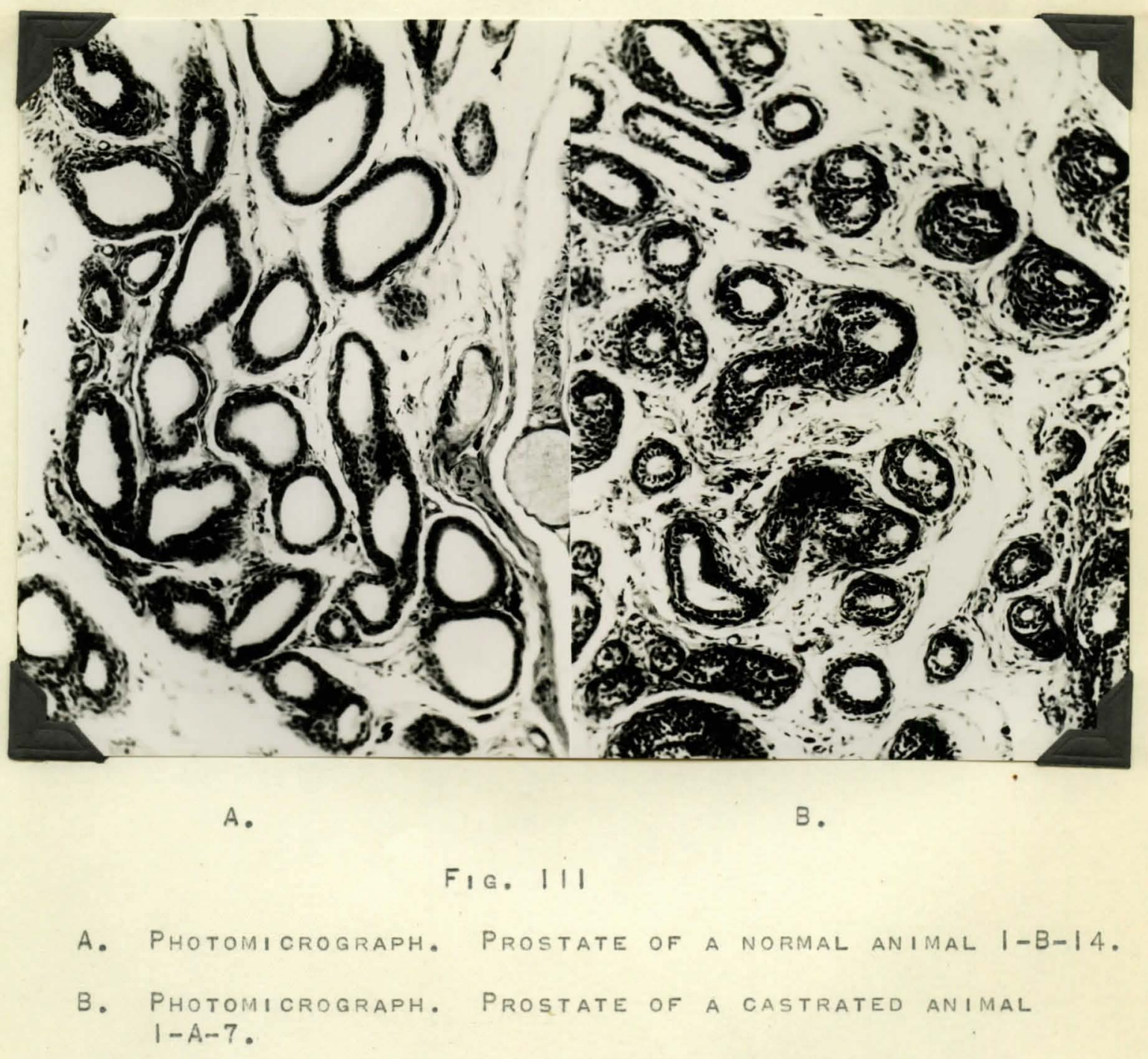


CHART NO. III

\author{
SERIES I-A \\ MALES \\ 33 Degrees C.
}

\begin{tabular}{|c|c|c|c|c|c|c|c|c|}
\hline \multirow[b]{2}{*}{$\begin{array}{l}\text { RAT. } \\
\text { No. }\end{array}$} & \multirow{2}{*}{$\begin{array}{l}\text { TYPE } \\
\text { OF } \\
\text { ANIMAL }\end{array}$} & \multirow{2}{*}{$\begin{array}{l}\text { DAYS } \\
\text { OF } \\
\text { OESER- } \\
\text { NATION }\end{array}$} & \multirow{2}{*}{$\begin{array}{l}\text { SEMINAL } \\
\text { VESICLE }\end{array}$} & \multirow{2}{*}{$\begin{array}{l}\text { PROS- } \\
\text { TATE }\end{array}$} & \multicolumn{2}{|l|}{ TRANSPLANTS } & \multicolumn{2}{|c|}{$\begin{array}{l}\text { URINARY } \\
\text { ANDROGENS }\end{array}$} \\
\hline & & & & & FOLLICULAR & LUTEINIZEO & $\begin{array}{l}\text { AVE, PRE- } \\
\text { OPERATIVE }\end{array}$ & $\begin{array}{l}\text { AVE.POST } \\
\text { OPERATIVE }\end{array}$ \\
\hline $1-A-2$ & C\&T & 42 & ++++ & - & +4 & $4+4$ & 1.20 .11$. & 1.4 C.J. \\
\hline $1-A-4$ & C\&T & 52 & ++++ & \pm & & $4+$ & I.2 c.u. & 0.0 c.J. \\
\hline $1-A-5$ & $C \& T$ & 52 & $4+4+*$ & $++^{*}$ & 4 & + & 1.2 & 1.2 \\
\hline$|-A-2|$ & C\&T & 75 & 4 & + & +++ & + & 0.8 & 1.3 \\
\hline $1-A-22$ & C\&T & 73 & $++4+$ & $+4+\infty$ & $\begin{array}{r}\text { TRANSPLANTS } \\
\text { NECRO }\end{array}$ & $\begin{array}{l}\text { LAREE, BUT } \\
\text { IC }\end{array}$ & 1.2 & 0.5 \\
\hline $1-A-23$ & C\&T & 75 & + & $\because$ & ++ & $+4+$ & 1.6 & 0.95 \\
\hline $1-A-25$ & C\&T & 76 & +4 & 4 & $4+$ & 4+ & 0.8 & 0.92 \\
\hline & & & & & & Ave. & $1.0 \mathrm{cos}$. & $0.8 \mathrm{cou}$. \\
\hline $1-A-7$ & c & 90 & $++++*$ & ++++ & & & 1.6 & 0.46 \\
\hline $1-A-10$ & N & 40 & - & - & & & 1.4 & c.u. \\
\hline $1-A-20$ & N & 74 & - & - & & & 0.91 & $1 \mathrm{C.U}$. \\
\hline
\end{tabular}

CODE: T INOICATES TRANSPLANTATION

C INDICATES CASTRATION

N NORMAL

* inoicates oegaeg of ataophy

* indicates degRe and trae of developicnt

C.U. Color Unit 
THE OVARIAN TRANSPLANTS OF THIS GROUP WERE NOT AS WELL DEVELOPED AND DID NOT CONTAIN AS MICH LUTEINIZED TISSUE AS THOSE OF THE ANIMALS WHICH WERE KEPT AT A HIGH TEMPERATIRE. (FIG. II-B). GROUP 111 . MALES.

THIS GROUP CONSISTED OF TEN ANIIALS OF WHIOH SEVEN WERE CASTRATED AND TRANSPLANTED, TWO WERE NORMAL AND ONE WAS Castrated. The latter three served as controls. These animals WERE KEPT in the incubator at 33 degress C. (Chart No. 111 ).

\section{ANROOOGENIC FINDIVGS:}

The aVERage postoperative androgenIC outPUt of THIS GROIP AS A WHOLE WAS LOWER THAN THE PREOPERATIVE AVERAGE. (CHART NO. 111).

\section{POOSTMORTIEM FINDINGS:}

THE PROSTATES AND SEMINAL VESICLES WERE NOT REMARKAELE GROSSLY. MICROSCOPIC EXAMINATION OF THE ACCESSORY TRACT REVEALED ATROPHY, EUT IT WAS MUCH LESS THAN THAT FOUND IN castrate animals. (FIgs. III, IV). The atrophy was more severe in the seminal VESICles than the PROStates.

THE OVARIAN TRANSPLANTS OF ALL ANIMALS WERE LARGE, WELl DEVELOPED, WELL VASCULAPIZED AND CONTAINED MANY LARGE corpora lutea and a FEV SMall Follicles. (Fig. V-A). GROUP IV. MALES.

THIS GROUP CONSISTED OF FOURTEEN ANIMALS, TEN OF WHICH WERE CASTRATED AND TRANSPLANTEO, TWO WERE NORMAL AND TWO were castrated. The latter four served as contgols. (Chart no. iv THIS GROUP WAS KEPT IN A LOW ENVIRONMENTAL TEMPERATURE (ZR DEGRESS C.).

ANDRROGGENIC FINEINGS: 


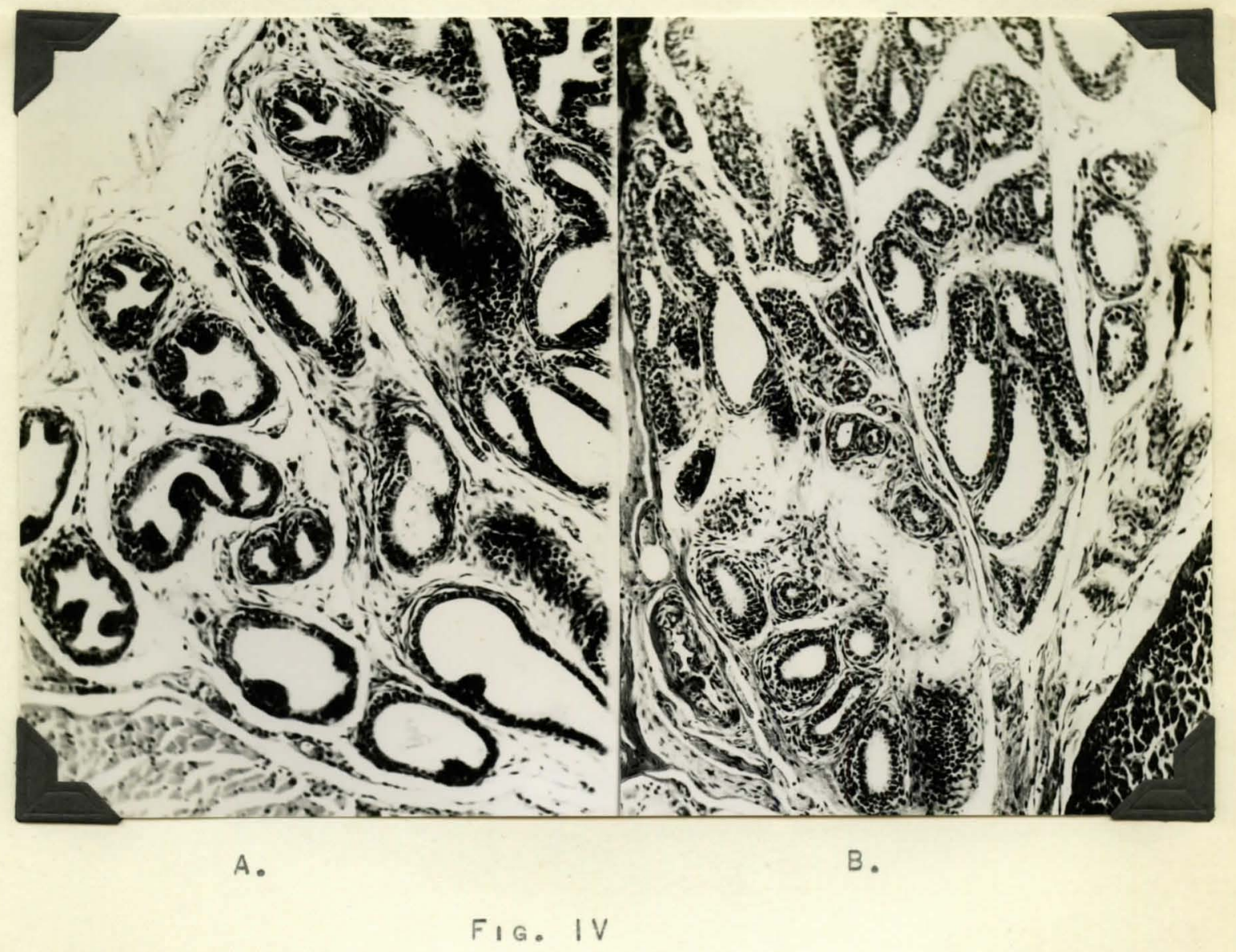

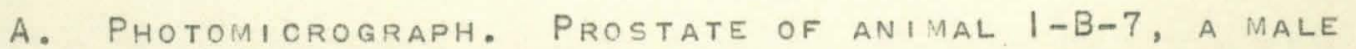
WHICH WAS CASTRATED, OVARIES TRANSPLANTED INTO THE EARS AND KEPT IN A LOW ENVIRONMENTAL TEMPERATURE (22 DEGRESS C.).

B. Prostate OF ANIMAL I-A-5, A MALE WHICH WAS CASTRATED, OVARIES TRANSPLANTED INTO THE EARS AND KEPT IN A HIGH ENVIRONMENTAL TEMPERATURE (33 DEgRESS C.). 
CHART NO. IV

SERIES I-B

MALES

22 DEgREES C.

\begin{tabular}{|c|c|c|c|c|c|c|c|c|}
\hline \multirow{2}{*}{$\begin{array}{l}\text { RAT. } \\
\text { No. }\end{array}$} & \multirow{2}{*}{$\begin{array}{l}\text { TYPE } \\
\text { OF } \\
\text { AN IMAL }\end{array}$} & \multirow{2}{*}{$\begin{array}{l}\text { DAYS } \\
\text { OF } \\
\text { OBSER- } \\
\text { VATION }\end{array}$} & \multirow{2}{*}{$\begin{array}{l}\text { PEMINAL } \\
\text { VESICL }\end{array}$} & \multirow{2}{*}{$\begin{array}{l}\text { PROS - } \\
\text { TATE }\end{array}$} & \multicolumn{2}{|c|}{ TRANSPLANTS } & \multicolumn{2}{|c|}{$\begin{array}{l}\text { URINARY } \\
\text { ANDROGENS }\end{array}$} \\
\hline & & & & & FOLLI CULAR & LUTEINIZEO & $\begin{array}{l}\text { AVE, PRE- } \\
\text { OPERATIVE }\end{array}$ & $\begin{array}{l}\text { AVE, POST } \\
\text { OPERAT I VE }\end{array}$ \\
\hline $\mid-8-1$ & C\&T & 71 & $+++*$ & ++ & + & + & $0.8 \mathrm{c} . \mathrm{U}$. & 1.7 \\
\hline $1-B-2$ & C\&T & 71 & \pm & \pm & ++ & & 0.8 & 1.0 \\
\hline $1-8-3$ & $C \& T$ & 71 & \pm & \pm & +++ & + & 1.2 & 1.04 \\
\hline $1-8-4$ & C\&.T & 72 & $+*$ & $+*$ & ++ & $4+$ & 1.2 & 0.6 \\
\hline $1-8-5$ & C\&T & 52 & $++++*$ & ++++ & \pm & & 2.4 & 0.6 \\
\hline $1-8-6$ & C\&T & 72 & $++^{*}$ & + & + & $4+$ & 1.2 & 1.12 \\
\hline $1-B-7$ & $C \& T$ & 71 & $+*$ & \pm & +++ & + & 1.2 & 0.56 \\
\hline $1-8-8$ & C\&T & 71 & +++ & $++^{*}$ & & +4 & 0.3 & 0.8 \\
\hline $1-3-9$ & C\&T & 71 & \pm & \pm & ++ & & 1.2 & 0.72 \\
\hline$|-8-10|$ & C\&T & 71 & +++ & $+*$ & $+4+4$ & ++ & 1.2 & 0.40 \\
\hline
\end{tabular}

Ave. $1.2 \quad 0.85$

\begin{tabular}{l|l|l|l|l|l|l|l|l}
\hline $1-8-12$ & $C$ & 71 & $++++^{*}$ & $+4+*^{*}$ & & & 3.2 & 0.24 \\
\hline $1-5-13$ & $\mathrm{C}$ & 71 & $++++^{*}$ & $+4++^{*}$ & & & 4.0 & 0.30 \\
\hline $1-8-14$ & $\mathrm{~N}$ & 71 & - & - & & & 1.30 .0$. \\
\hline $1-B-15$ & $\mathrm{~N}$ & 71 & - & - & & & 1.60 .0$. \\
\hline
\end{tabular}

CODE: T INOICATES TRANSPLANTATION

C INOICATES CASTRATION

N. NORMAL

- indicates degreg of atrophy

+ indicates degre and trpe of oevelopment

C.U. Color UnIt 


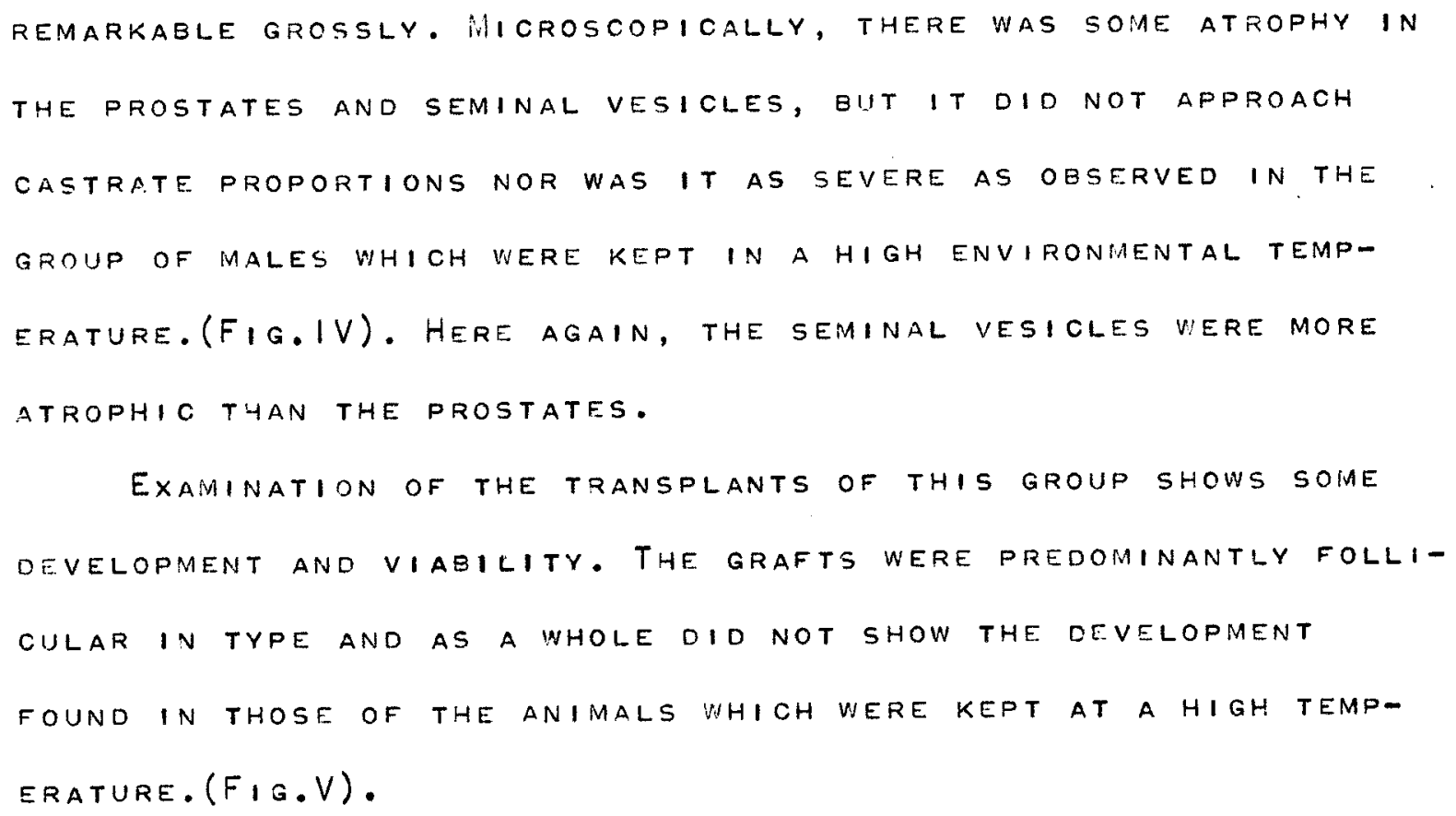




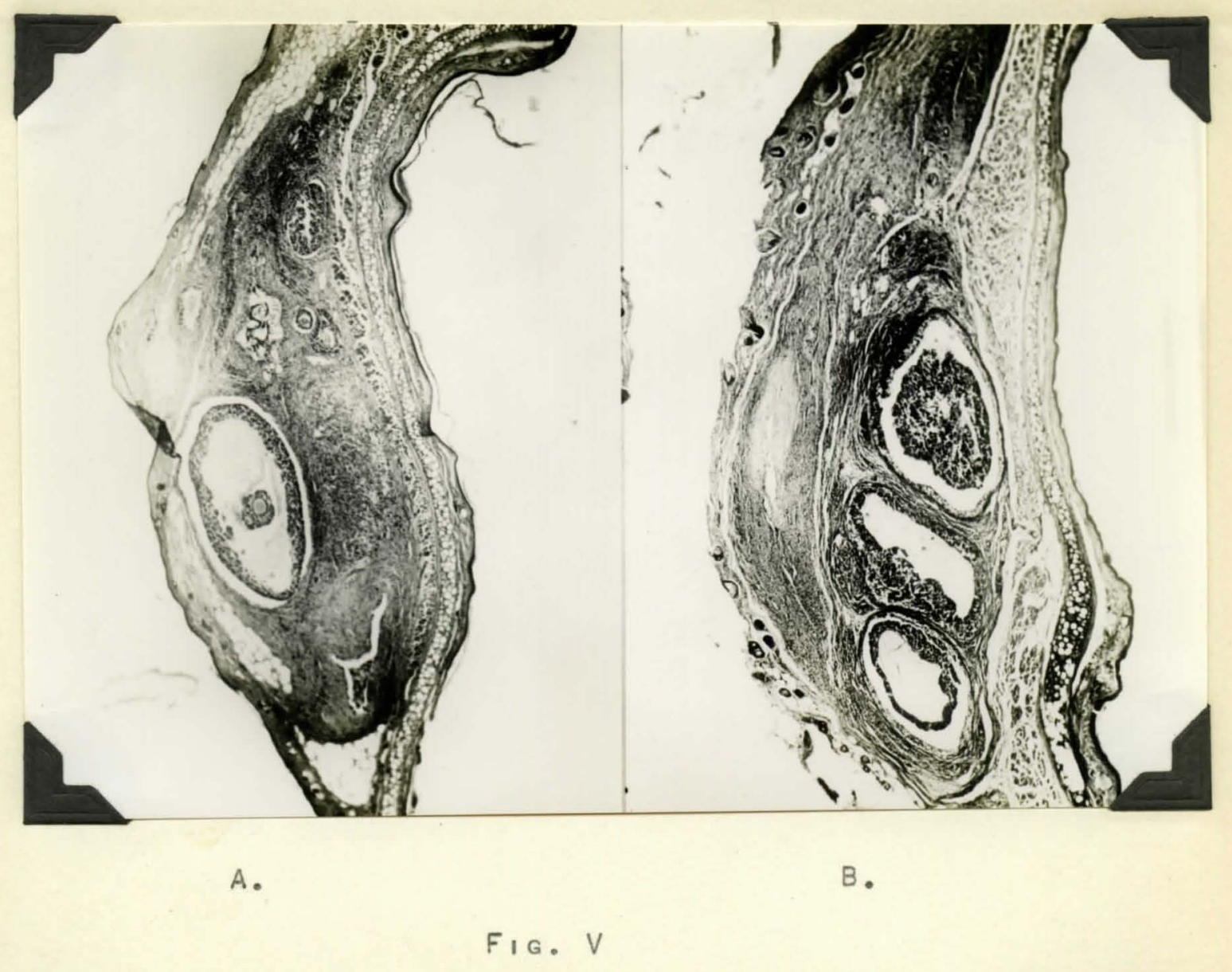

A. PHOTOMICROGRAPH. CROSS SECTION THROUGH PORTION OF EAR CONTAINING OVARIAN TRANSPLANT OF ANIMAL I-A-5, A MALE WHICH WAS CASTRATED, OVARIES TRANSPLANTED INTO THE EARS AND KEPT IN A HIGH ENVIRONMENTAL temperature ( 33 DEgRESS C.).

B. Same of a similarly treated MALE, I-B-7, Kept in a LOW ENVIRONMENTAL TEMPERATURE (22 DEGRESS C.). 
DISCUSSION 
FroM the DATA CONCERNING THE TNO GROUFS OF FEMALES, IT AT ONCE EECOMES OGVIOUS THAT TO SOME EXTFNT, AT LEAST, THE OESTROGENIC ACTIVITY OF THE OVARY CAN BE CONTROLLED BY TRANSPLANTATION AND TEMPERATURE REgULATION. IT SEEMS THAT OVARIES IN THE EARS OF ANIMALS VIHICH ARE KEPT AT A HIGH TEMPERATURE HAVE THE POWER OF PREVENTING THE USUAL CASTRATION CHANGES IN THE UTERUS, WHEREAS THOSE IN THE EARS CF ANIMALS WHICH ARE KEPT AT A LOW TEMPERATURE DO NOT HAVE THIS POWER.

THERE ARE THO FACTORS WHIOH MUET EE CONSIDERED IF AN ATTEMPT IS MADE TO EXPLAIN THIS PHENOMENON. THE FIRST OF THESE FACTORS IS TEMPERATURE, WHISH, IT SEEMS MAY INFLIENCE OVARIAN FUNCTION IN TWO WAYS: (I) BY OIRECTLY INHIBITING THE INTERNAL SEGRETORY ACTIVITY, (2) BY INTERFERING WITH THE DEVELOPMENT OF THE OVARY AND THUS INDIRECTLY INFLUENCING THE INTERNAL SECRETORY ACTIVITY. SECTIONS OF THE TRANSPLANTS OF THE LOW TEMPERATURE ANIMALS SHOIY THAT THE TRANSPLANTS DO NOT TAKE NOR OEVELOP AS VELL AS THOSE OF ANIMALS WHICH ARE KEPT IN A HIGH ENVIRONMENTAL TEMPERATURES. (FIG.|1). THEREFore, THE castration CHANGES WHI CH DEVELOP MAY NOT BE DUE TO A COIPLETE ABSENCE OF OVARIAN HORMONE, BUT RATHER TO A SUB-THRESHOLD AMOUNT OF THE HORMONE.

THE SECOND FACTOR TO BE CONSIDERED INVOLVES THE POSSIRILITY OF THE PRODUCTION OF AN ANDROGEN EY TZANSPLANTED OVARIES WHICH ARE KEPT COOL BY A LON ENVIRONMENTAL TEMPERATURE.

- the literature given in the first part of this paper shows THAT ANDROGENIC SUBSTANCES SUCH AS TESTOSTERONE PROPIONATE, WHEN INJECTED INTO INTACT FEMALE RATS OVER A LONG PERIOD OF TIME WILL PRODUCE ATROPHY OF THE GENITAL TRACT, WITH A SUPPRESSION OF THE OESTRUS CYCLE AS LONG AS THE INJECTIONS ARE 
METHOD CANNOT EE DISTINGUISHED FROM THE USUAL CASTRATION CHANGES, IT IS IMPOSSIBLE TO DETERMINE WHETHER THE ATROPHY OBSERVED IN OUR SERIES IS DUE TO THE ACTION OF ANDROGENS OR TO THE LACK OF OVARIAN FUNCTION.

$$
\text { IT IS IMPORTANT TO NOTE, HOWEVER, THAT THE CLITORA OF ALL }
$$

ThE FACT THAT THE URINARY ANDROgENS OF THE FEMALES KEPT AT A LOW TEMPERATURE WERE DECREASED POSTOPERATIVELY MAY BE DUE IN PART TO THE RATHER POOR DEVELOPMENT OF THEIR TRANSPLANTS. THIS DECREASE IS NOT AS MARKED, HOWEVER, AS THAT OBSERVED IN CASTRATE ANIMALS. THIS POINTS TOWARD THE POSSIBILITY THAT THESE TRANSPLANTED OVARIES ARE PRODUCING ANDROGENIC SUBSTANCES.

IT SEEMS AT PRESENT THAT PERHAPS THE ATROPHY OF THE UTERI OF THE FEMALES WHICH WERE KEPT AT A LOW TEMPERATURE IS DUE TO BOTH FACTORS DISCUSSED AEDVE, AND THAT PERHAPS THE EFFECT OF A DECREASED OUTPUT OF OESTROGENIC HORMONE BY THE OVARIES IS POTENTIATED BY THE ACTION OF AN ANDROGENIC SUBSTANCE COMING FROM THE SAME ORGAN.

OBSERVATIONS ON THE GROUPS OF MALE ANIMALS INDICATE THAT TO SOME EXTENT, THE USUAL CASTRATION CHANGES CAN BE PREVENTED 
BY TRANSPLANTING OVARIES INTO THE EARS OF CASTRATE MALES. THE EXILANTION FOR THIS IS VAGUE. THE WORK OF GREENE, BURRIL, AND IVYIO ON THE ANDROGENIC ACTIVITY OF PROGESTERONE MAY OFFER A POSSIBLE EXPLANATION, NAMELY, THAT THESE TRANSPLANTED OVARIES DRODUCE ENOUGH PROGESTERONE TO PREVENT THE CASTRATION CHANGES. THERE IS MUCH EVIDENCE AGAINST THIS. FIRST, THOSE MALES VHICH WRE KEPT IN THE INCUBATOR AT A HIGH TEMPERATURE SHOM MORE ATROPHY IN THE PROSTATES AND SEIANAL VESICLES THAN DO ANIMALS WHICH ARE MAINTAINED AT ROOM TEMPERATURE. (Fig. IV). ThE transplantS OF ANIMALS KEPT AT A HIGH TEMPERATURE SHOW BETTER DEVELOPMENT AND MORE LUTEINIZATION THAN DO THOSE OF AMIMALS WHICH ARE KEPT AT A LOW TEMPER TURE. IF THE PREVENTION OF THE CASTRATION CHANGES IS DUE TO THE ACTIVITY OF PROGESTERONE, ONE WOULD FXPECT LESS ATROPHY IN THE PROSTATES AND SEMINAL VESICLES OF THE ANIMALS KEPT IN THE INGUBATOR, SINCE THEIR TRANSPLANTS ARE LARGER AND SHOW MORE LUTEINIZATION THAN THOSE OF ANIMALS WHICH. ARE KEPT AT A LOW TEMPERATURE.

OTHER EVIDENCE AGAINST THIS IDEA IS THE FACT THAT THE FEMALES MHICH WTRE TRANSPLANTED AND KEDT AT a LOM TEMDERATURE SHOWED IITERI WHICH WERE ATROPHIC. (FIG. I-B). FROM THIS IT IS POSSIGLE TO at LEAST PARTLY RULE OUT THE ACTION OF ESTRIN OR. PORGESTIN IN THE ACTIVATION OF THE ACCESSORY TRACT.

ANOTHER EXOLANATION IS THAT THE CASTRATION CHANGES HAVE NOT HAD TIME TO OEVELOP. THIS DOSSIBILITY CAN BE RULED OUT BY EXAMINING A CASTRATE CONTROL ANIMAL, WHICH IN THE SAME LENGTH of time had deVEloped full elown castration changes. (FIG. III).

A FINAL EXPLANATION LIES IN THE POSSIEILITY THAT OVARIES, WHEN TRANSPLANTEO TO THE EARS AND KEPT COOL BY A LOW ENVIRON- 
MENTAL teMPER TURE MAY PRODUCE ANDROgEnic SUBSTANCES. THE URINARY ANDROGENIC FINOINGS ON THESE ANIMALS OFFER SOME EVIDENCE FOR THIS. IT IS TRUE THAT THE AVERAGE POSTOPERATIVE LEVEL OF BOTH GROUPS OF MALES WAS LOWER THAN THE PREOPERATIVE AVERAGE. THIS IS TO $9 E$ EXPECTED, FOR EVEN IF THESE DVARIES ARE PRODUCING MALE HORMONES, THEY VOULD NOT EE EXPECTED TO PRODUCE AS MIJCH HORMONE AS DO THE TESTES. IT IS ALSO TRUE THAT THE POSTOPERATIVE LEVELS IN THESE groHPS WERE NOT AS LOW AS THOSE OF THE CASTRATE CONTROLS. THIS SEEMS TO INDICATE THAT thesE TRANSPLANTED OVARIES ARE PRODUCING A MALE HORMONE, OR SOBE SUBSTANCE WHICH IS PHYSICLOGICALLY AND CHEMICALLY SIMILAR TO THE MALE HORMONES. THE ANDROGENIC FINDINGS ARE SOMEUHAT HARD TO EVALUATE. DUE TO THE SAALL AMOUNT OF URINE MHICH IS AVAILABLE AND TO VARIOUS FLANS IN THE COLORIMETRIC TECHINIQUE WHICH MIGHT LEAD TO ERRORS, THEY WOULD BE OF LITTLE VALUE WITHIN THEMSELVES. HOWEVER, SINCE THEY CAN EE CORRELATED WITH THE HISTOLOGICAL CHANGES, IT IS BELIEVED THAT THEY ARE OF SOME SIGNIFICANCE. THE POSITIVE CORRELATION BETWEEN THE ANOROGENIC AND HISTOLOGICAL FINDINGS MERELY ADDS TO THE CONCLUSIVENESS OF THE LATTER. 
CONCLUSICNS 
1. THE OESTROgENIC ACTIVITY OF THE OVARIES IS INHIEITED IF THEY ARE TRANSPLANTED TO THE EARS, AND KEPT COOL BY A LOW ENVIRONMENTAL TEMPERATURE.

2. THE OESTROGENIC ACTIVITY OF OVARIES TRANSPLANTED TO THE EARS IS NOT COMPLETELY INHIEITED, BUT ALTERED QUANTITIVELY (AS MANIFESTED EY VAGINAL SMEAR STUDIES) IF THE ANIMALS ARE KEPT IN A HIGH ENVIRONMENTAL TEMPERATURE.

3. THE castration changes can Be PREVEnTED IN MALE rats by TRANSPLANTING OVARIES INTO THE EARS. THIS EFFECT IS MORE MARKEO IN THE ANIMALS WHICH ARE KEPT IN A LOM ENVIFONMENTAL temperature (22 degrees C.) THAN IN those kePt IN A HIGH ENVIRONHENTAL temperature (33 Degrees C. ).

4. TRANSPLanted OVARIES KEPT WARM BY a HIGH ENVIRONMENTAL TEMPERATURE DEVELOP BETTER AND SHOW MORE LUTEINIZATION THAN DO THOSE WHICH ARE KEPT COOL BY A LOW ENVIRONMENTAL TEMPERATURE. 
SUMMARY 
Male and female rats were castrated, ovaries transplanted SUECUTANEOUSLY INTO EACH EAR AND DIVIDED INTO TWO GROUPS, ONE CONSISTING OF MALES ANE FEMALES KEPT AT A CONSTANT TEMPERATURE OF 33 DEGREES C. IN AN INCUBATOR, THE OTHER CONSISTING OF MALES and females kePt at Room temperature (22 degrees C.).

THESE ANIMALS WERE OBSERVED FOR PERIODS OF $52-122$ DAYS, DIRING WHICH TIME THE URINE OF BOTH MALES AND FEMALES WAS ANALYZED COLORIMETRICALLY FOR ANDROGENIC SUBSTANCES, AND THE VAGINAL EPITHELIUM STUDIED BY MEANS OF SMEARS.

At the time the animals were killed, the ovarian transPLANTS, UTERI, SEMINAL VESICLES AND PROSTATES WERE STUDIED MICROSCOPICALLY.

THE DATA OBTAINED FROM THESE EXPERIMENTS SEEM TO INDICATE THAT THE INTERNAL SECRETORY ACTIVITY OF THE OVARY CAN BE INFLIJENCED BY TRANSPLANTATION AND TEMPERATURE. THE UTERI OF THE ANIMALS KEPT AT ROOM TEMPERATURE WERE ATROPHIC INDICATING A LACK OF OVARIAN FUNCTION, WHEREAS THE PROSTATES ANO SEMINAL VESICLES OF THE MALES KEPT AT ROOM TEMPERATURE SHOWED EVIDENCE OF ANDROGENIC STIMULATION.

THE ANIMALS KEPT AT A HIGH TEMPERATURE SHOWED UTERI WHICH WERE NOT ATROFHIC, INDICATING OVARIAN FUNCTION. THE SEMINAL VESICLES AND PROSTATES WERE SOMEWHAT ATROPHIC, BUT SHOWEO DEFINITE EVIDENCE OF ANDROGENIC STIMULATION. 
REFERENCES 
1. Gardner, W.U. The effect of OVarian Hormone and ovarian Grafts on the Mammary glands of Male Mice. ENDOCRINOLOGY 19:656 1935

2. Hill, r.t. ovaries secrete male hormone.

1. Restoration of the castrate type of Seminal

Vesicle and Prostate glands to inormal by Grafts of OVARIES.

ENDOCRINOLOGY 21 MARCH 1937 495-502.

11/. Temperature Control of male hormone OUtPut by GRAFted OVARIES.

ENDOCRINOLOGY 21 SEPT.1937 633-636.

3. Hill, R.t. and M.T.Strong. Ovaries secrete male hormone.

IV. EFFECT OF OVARIAN ANDROGEN ON ACCESSORY

SIZE IN THE MOUSE.

ENOOCRINOLOGY $22 \quad 1938 \quad 663-666$.

4. Deansely, Ruth. The Androgenic activity of ovarian grafts in Castrateo Male rats.

Proc.royal Soc. Series B. BIOLOGICAL SCIENCE. NO.842 VOL. I26 SEPT. 1938

5. Nelson and Merckel. Effects of androgenic substances in the

Female Rat.

PROC.SOC.EXP.BIOL.AND MED. 36:823-825

6. greene, Burril and IVy. Masculinization of female rats by

Post natal administration of Male sex hormones.

PROC.SOC.EXP.3IOL.AND MED. 38 4-5 1938 .

7. Greene and IVy. The experinental Production of intersexuality in the female rat with testosterone.

SCIENCE 86:200 1937 
8. Salmon, U.j. The Effect of testosterone propionate dn the genital tract of the immature female rat. ENDOCRINOLOGY VOL.23 NO.6 779-784 DEC.I938.

9. Mazer, Milton and Charles Mazer. The effect of Prolongeo

Testosterone Propionate administration on

the Immature and Mature female rat.

ENDOCRINOLOGY VOL.24 NO.2 FEB.1939.

10. Greene, Burril and IVY. Progesterone is androgenic.

ENDOCRINOLOGY 24 No.3 351 MARCH 1939.

11. Oesting, Ralph B. a Colorimetric assay fo Male sex hormones IN URINE.

PROC.SOC.EXP.BIOL.AND MED. 36:524-526. 